\title{
皮膚の機能・特性と物理計測
}

\author{
高 橋 元 次 \\ エムティーコンサルティング 画 236-0005 神奈川県横浜市金沢区並木 2-12-1-303
}

（2013 年 9 月 29 日受付；2013 年 10 月 26 日掲載決定)

\section{Functions/Characteristics of the Skin and Physical Measurements}

\author{
Motoji TAKAHASHI \\ MT Consulting, 2-12-1-303 Namiki, Kanazawa-ku, Yokohama, Kanagawa 236-0005
}

(Received September 29, 2013 ; Accepted October 26, 2013)

\begin{abstract}
Many bioengineering techniques to elucidate functions and characteristics of the skin have been developed until now. They measure the water content of stratum corneum, transepidermal water loss (TEWL), skin surface contour, mechanical properties, blood flow, sebum secretion rate, wrinkles, skin pigmentation and so on. These instrumental measurements are applied to validation of the efficacy of the cosmetics. Recently, a few in vivo bio-microscopes which non-invasively visualize horizontal image or vertical cross section of the skin with subcellular resolution, have been developed by using non-linear optics phenomenon. In this paper, I describe how skin measurement technologies have been changed with time and applied to cosmetic science, and also review in vivo bio-microscopes, they are optical coherence tomography (OCT), confocal laser scanning microscope (CLSM), second harmonic generation (SHG) microscope, multi photon microscope (MPM), and coherent anti-Stokes Raman scattering (CARS), which will be very helpful to examine the effects of the cosmetics on the skin.
\end{abstract}

KEYWORDS : skin bioengineering, efficacy test, bio-microscope, skin measurement, non-invasive method

\section{1.は じめに}

皮膚の機能や生理特性，さらには内部構造に関して皮 膚を傷つけずに表面から，接触あるいは非接触で測定す る機器が多く開発されている。測定対象は皮膚の保湿機 能やバリア機能, キメやシワなどの皮膚表面形状, 力学 特性, 光学特性, 発汗, 皮脂分泌, 皮膚血流, 代謝活性 など幅広い。これらは主に機器を用いた物理計測である が，これ以外に非侵襲的に肌状態を調べる方法として， 粘着テープで皮膚表面の角層を 1 層剥がして角層中のサ イトカインや酵素活性を調べるなど生物化学的なやり方 もある。いずれの方法も化粧品研究において肌状態や有 効性の評価などに広く用いられている。

皮膚の物理計測に関しては Table 1 に示すように計測 技術の進歩とともに大きく変化した。たとえば，角層水 分量測定において以前は皮膚表面の電気特性から間接的

E-mail : ttn85sz28p@mx4.ttcn.ne.jp
に推定していたが，最近では in vivo 共焦点ラマン顕微 鏡によって水分子を測定し，角層・表皮の深さ方向にお ける分布状態について詳細に検討できるようになってき た。また, 皮膚内部の観察においては, 超音波や MRI (Magnetic Resonance Imaging) を用いた断層撮影以外に, OCT (Optical Coherence Tomography : 光干涉断層撮影 法), in vivo 共焦点レーザー走查型顕微鏡（confocal laser scanning microscope : CLSM), SHG 顕微鏡（Second Harmonic Generation：第二高調波発生), 多光子(励起蛍 光）顕微鏡（multi photon microscope: MPM), CARS (Coherent Anti-Stokes Raman Scattering) 顕微鏡など，生 体顕微鏡とよばれる新しい測定機器が多く開発され，皮 膚の組織構造だけでなく皮膚内の成分分析も可能になっ てきている。

本稿では Table 1 に掲げた項目の中から化粧品の機能 評価において基本と考えられている保湿（角層水分量）, バリア, キメ, 力学特性, シワ, シミの測定について述 ベるとともに, 最近, 進歩の目覚ましい生体顕微鏡の活 
Table 1. Skin functions/characteristics and in vivo measurements.

\begin{tabular}{|c|c|c|c|}
\hline skin functions/characteristics & $1^{\text {st }}$ generation methods & $2^{\text {nd }}$ generation methods & $3^{\text {rd }}$ generation methods \\
\hline $\begin{array}{l}\text { skin hydration (water content } \\
\text { of stratum corneum) }\end{array}$ & $\begin{array}{l}\text { - electrical properties } \\
\text { (Skicon, Corneometer) }\end{array}$ & $\begin{array}{l}\cdot \text { ATR-FTIR } \\
\cdot \text { NIR }\end{array}$ & $\begin{array}{l}\text { - in vivo confocal Ramann } \\
\text { spectroscopy }\end{array}$ \\
\hline $\begin{array}{l}\text { Skin barrier } \\
\text { (TEWL) }\end{array}$ & $\begin{array}{l}\text { closed chamber (Meeco, } \\
\text { Vapometer, AquaFlux) }\end{array}$ & $\begin{array}{l}\text { - open chamber } \\
\text { (Evaporimeter, Tewameter) }\end{array}$ & \\
\hline $\begin{array}{l}\text { skin surface topology } \\
\text { (texture, scaling, wrinkle) }\end{array}$ & $\begin{array}{l}\text { - replica 2D analysis } \\
\text { - Dermascope }\end{array}$ & $\begin{array}{l}\text { - replica 3D analysis } \\
\text { (laser 3D profilometer) }\end{array}$ & $\begin{array}{l}\text { - in vivo 3D analysis } \\
\text { (PRIMOS, Derma-Top } \\
\text { Blue) }\end{array}$ \\
\hline skin mechanical properties & $\begin{array}{l}\text { - Stress-strain curve } \\
\text { - forced oscillation } \\
\text { - suction cup(Cutometer) } \\
\text { - mechanical impedance }\end{array}$ & $\begin{array}{l}\cdot \text { resonance frequency } \\
\text { (Venustron) } \\
\cdot \text { acoustic impedance } \\
\cdot \text { air pressure (non-contact) }\end{array}$ & \\
\hline skin internal structure & $\begin{array}{l}\cdot \text { ultrasonography } \\
\cdot \text { MRI }\end{array}$ & $\begin{array}{l}\text { - OCT (functional OCT) } \\
\text { - in vivo CLSM }\end{array}$ & $\begin{array}{l}\cdot \mathrm{SHG} \\
\cdot \mathrm{MPM} \\
\cdot \mathrm{CARS}\end{array}$ \\
\hline $\begin{array}{l}\text { skin color } \\
\text { pigmentation } \\
\text { erythema }\end{array}$ & $\begin{array}{l}\cdot\left(\mathrm{L}^{*} \mathrm{a}^{*} \mathrm{~b}^{*}\right) \\
\cdot(\mathrm{H}, \mathrm{V}, \mathrm{C})\end{array}$ & $\begin{array}{l}\cdot \text { melanin content in skin } \\
\cdot \text { hemoglobin content in skin } \\
\text { (ex. Mexameter) }\end{array}$ & $\begin{array}{l}\text { melanin distribution in } \\
\text { epidermis } \\
\text { (CLSM MPM) }\end{array}$ \\
\hline skin blood flow & $\begin{array}{l}\cdot \text { laser Doppler } \\
\text { (single point measurement) }\end{array}$ & $\begin{array}{l}\cdot \text { laser Doppler } \\
\text { - laser speckle } \\
\text { (2D measurement) }\end{array}$ & $\begin{array}{l}\text { Doppler-OCT } \\
\quad \text { (functional OCT) }\end{array}$ \\
\hline epidermal cell proliferation & $\begin{array}{l}\text { turnover time of stratum } \\
\text { corneum (dansyl chloride, } \\
\text { surface area of corneocyte) }\end{array}$ & $\begin{array}{l}\text { - in vivo fluorescence spectrum } \\
\text { (tryptophan, } \mathrm{NAD}(\mathrm{P}) \mathrm{H})\end{array}$ & \\
\hline $\begin{array}{l}\text { anti-oxidation } \\
\text { ROS, AGE }\end{array}$ & $\begin{array}{l}\cdot \text { EPR } \\
\cdot \text { chemiluminescence } \\
\text { - AGE Reader }\end{array}$ & & \\
\hline
\end{tabular}

用について紹介する。なお, in vivo 共焦点ラマン顕微 鏡, CLSM, SHG 顕微鏡, MPM については, 本誌, 皮 膚計測技術の最新動向（平尾哲二他）を参考にして戴き たい。

\section{2. 角層水分量測定}

外気が乾燥すると皮膚の最外に位置する角層中の水分 量は低下し, 表皮ターンオーバーが充進して機能の劣っ た角層が形成される。その結果, 皮膚バリア機能や保湿 機能が低下し, 角層はさらに乾燥してキメは悪化し, 表 面には鱗屑が生じざらつき, 肌の透明感や柔軟性が失わ れる。このように角層中の水分量は皮膚の恒常性や美し さを維持するうえで重要な役割を果たしており, その測 定には様々な機器が用いられている。

\section{1 高周波電流法}

$\mathrm{MHz}$ 程度の高周波電流を皮膚表面に流し皮表コンダ クタンスあるいはキャパシタンスを測定する。皮表の水 分量が多いほど測定值が高くなることを利用した測定器 で, skicon ${ }^{\mathrm{TM}}$ や Corneometer ${ }^{\mathrm{TM}}$ など多くのものが市販さ れている。測定深度, 再現性, ダイナミックレンジ（測 定域）などにおいてそれぞれ特徵があるものの機種間の
相関は高い ${ }^{1)}$ 。電極を一定の圧力で数秒間皮膚に押しつ けるだけで容易に測定できるが，周囲の環境条件に影響 されやすいので温度 $20 \sim 22^{\circ} \mathrm{C}$, 湿度 $50 \%$ 前後など発汗 の影響のない一定環境下で行う。測定值は NMF（Natural Moisturizing Factor。角層中に存在する遊離アミノ酸 を主成分とする吸湿性の高い物質）量ときわめて良い相 関 ${ }^{2)}$ があるが, 測定深度は明確ではなく角層および表皮 生細胞層の一部を測定していると考えられている。

\subsection{ATR-FTIR 法 (Attenuated Total Reflectance-} Fourier Transform Infrared)

赤外線吸収スペクトルを用いた方法である。皮膚に対 する測定深度は $1 \mu \mathrm{m}$ 程度で角層表面の水分を測定して いる。アミド I $\left(1645 \mathrm{~cm}^{-1}\right)$ の吸収は蛋白と水分の影響 を受けるが，アミドII $\left(1545 \mathrm{~cm}^{-1}\right)$ は蛋白の影響だけ なので二つの吸収の比（アミド I/アミド II ; MF moisture factor）を用いて相対的な水分量が測定できる。アミド I, II のピーク以外では, $2100 \mathrm{~cm}^{-1}$ 近辺のブロードな水 の吸収ピークを用いる ${ }^{3)}$ 。

赤外吸収によるこの方法は角層水分量だけでなく角層 細胞間脂質の規則性や量的な検討, また結晶構造につい ても情報が得られるのでテープストリッピングを繰り返 
しながら測定すれば深さ方向において，水，脂質に関し て様々な観点から検討できる4)。

\section{3 近赤外線分光法 (Near Infrared Spectroscopy： NIRS)}

近赤外の波長領域で水分子は二つの明瞭な吸収带

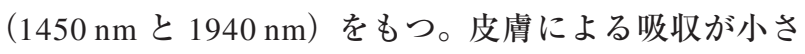
い $1100 \mathrm{~nm}$ （比較するための基準值）と水分子による吸 収の大きい $1940 \mathrm{~nm}$ のピーク差は $\mathrm{Skicon}^{\mathrm{TM}}$ で測定した 值やドライスキンの臨床スコアと良く対応することが報 告されている5)。しかし, 近赤外光は皮虐内一の到達樑 度が媣く (数百 $\mu \mathrm{m}$ 程度), $1940 \mathrm{~nm}$ のピーク強度は角 層の水分だけでなく表皮生細胞層や真皮層の水分の影響 も受けるので，この方法を用いて角層水分量を推定する 場合は注意しなければいけない。一方，短時間（1２ 時間程度）に打けるワセリンやクリーム塗布による皮虐 水和効果を調べる場合は, 表皮生細胞層や真皮層に打け る水分の変動は小さいので, 測定された水分量の変化は 塗布によって生じたと考えてよい。NIRS は皮虐に接触 せずに測定できるので塗布物が表面に残っている場合で も評価可能である。

以前から顔面全体に扔ける水分の分布状態を NIR 画 像で撮影されてきたが, 専ら用いる光の波長領域は 1000 1700 nm で感度が低かった。最近，1000〜2200 $\mathrm{nm}$ の波長領域で撮影可能な NIR カメラが開発され, 水 による吸収の最も大きい $1950 \mathrm{~nm}$ 近辺のピークから水 分を, $1775 \mathrm{~nm}$ 近辺のピークから油分を測定する方法が 提案され, 素顔だけでなく化粧品塗布による水分, 油分 の変化を同時に調べることが可能である6。

\section{4 磁気共鳴画像法 (MRI : Magnetic Resonance Imaging)}

プロトン $\left({ }^{1} \mathrm{H}\right)$ のシグナルを検出して皮䖉深さ方向 に扔ける水の分布状態を断層像で示す方法である。通常 の MRI では深さ方向の分解能が $50 \mu \mathrm{m}$ 程度で顔面や前 腕などの角層（10２0 $\mu \mathrm{m}$ 程度の厚さ）をターゲットに して測定することは難しく，指先や踵のように厚い部位 (角層厚は $100 \mu \mathrm{m}$ 程度)に限られ, ワセリン叙布の影 響や水浸漬による変化などが検討されてきた ${ }^{7)}$ 。最近, GARfield（Gradient At Right angles to field）MRI を用い て $10 \mu \mathrm{m}$ 以下の分解能で測定できるようになり, 緩和 時間 $\mathrm{T}_{1}$ から水分を, $\mathrm{T}_{2}$ から $\mathrm{NMF}$ を求め, 深さ方向に おける分布状態が調べられている ${ }^{8}$ 。後述する in vivo 共 焦点ラマン分光法で得られた結果とも比較的良い対応が 認められており, また水分量だけでなく水の特性（結合 水など）や ${ }^{31} \mathrm{P}$ にいても調べることができるので，今 後，肌評価への適用が期待される。

\section{5 in vivo 共焦点ラマン分光法（Confocal Raman} Spectroscopy : CRS)

ある物質に振動数 $\nu_{0}$ の光が照射されると入射光と等 しい振動数をもつ散乱光（レイリー散乱）以外に振動数 が $\nu_{0}$-レ（ストークス）あるいは $\nu_{0}+\nu （$ アンチストー クス）の弱い光（ラマン散乱光）が散乱される。入射光 とラマン散乱光の振動数の差 ( $(2)$ をラマンシフトとい い，この值は分子構造（官能基）に固有の値を示すので レの分布状態（ラマンスペクトル）から物質の構造がわ かる。一般的には入射光より振動数の小さいストークス 散乱光が解析され, 共焦点ピンホールを装着することに より深さ方向の情報が得られる。

近年, in vivo 共焦点ラマン顕微鏡 (9)用いて，角層を 含む表皮中の深さ方向に扔ける水分や NMF の分布状態 が調べられている。前腕に扔ける角層中の水分布は皮虐 表面から内部に向かって増加し, 約 15〜20 $\mu \mathrm{m}$ の媣さ でほほ一定になる。この值が角層の厚さに相当する。こ れまで角層水分量測定に使われてきた高周波電流法も NIRS も測定深度が明確でなくどこまでの深さの水分を 測っているのかについては不明であったが, 初めて in vivo で角層・表皮の深さ方向に打ける水分量変化を調べ ることが可能になった。また, 水分や NMF 以外の生体 成分や皮虐に塗布された薬剤の分布状態などについても 調べることができる。

\section{3. 皮膚バリア機能測定}

皮虐には様々な防御機能があり,これらのほとんどは 角層が担っている ${ }^{10)}$ 。防御機能はそれぞれの作用に対応 して抗酸化 (バリア) 機能, 抗微生物 (バリア) 機能な どとよばれているが, その中で最も重要な機能が「透過 に対するバリア機能」なので, これを単にバリア機能と 略すことが多い。透過に対するバリア機能には外界から の異物の侵入に対する防御作用（out-in barrier）と体内 からの過剩な水分の蒸散を抑え乾燥から生体を守る防御 作用（in-out barrier）がある。両方を合わせて透過に対 するバリア機能とよんで扔り，角層と表皮顆粒層にある タイトジャンクションが関与している。in-out barrier は 角層水分量とならんでスキンケアを考えるうえで重要な 皮虐特性で, 体の内側から外側に向かって単位時間, 単 位面積当たりに蒸散する水分量 $\left[\mathrm{g} / \mathrm{m}^{2} / \mathrm{hr}\right]$ ，すなわち， TEWL（transepidermal water loss：経表皮水分損失量）で 表され，測定には様々な機器が用いられている ${ }^{11}$ 。

一方, out-in barrier を測定する市販機器はないが, 最 近, 水溶性着色料を皮虐に一定時間, 接触させた後の皮 膚色を測定し, その変化から皮膚のバリア機能を簡便に 調べる方法が提案されている ${ }^{12)}$ 。皮膚色の変化が大きい 
ほど皮膚バリア機能が劣っていると考える。タートラジ ンを生理食塩水に溶解させ, その水溶液を皮虐に接触さ せた後, 皮膚色 $\left(\mathrm{b}^{*}\right)$ を測定し, $\mathrm{b}^{*}$ の増加率からバリ ア機能を評価する。この方法はいくつか問題点を残して はいるものの, TEWL 測定とは違う原理で外部からの 物質の浸透性を調べ，バリア機能を評価しているので両 者を平行して行えば皮虐バリアに対する新たな切り口に なると思われる。

\section{4. キ メ 測 定}

皮溝と皮丘で織りなされた皮䖉表面の紋様はキメとよ ばれる。キメが整っていると皮虐内部反射光が増え, 肌 の透明感が上がり, キメの良さは美しい肌の条件の一つ である。また，皮䖉が伸展されたときキメはその応力を 緩和して簡単に角層が破断されないように働く。

キメを調べるには大別して2 通りの方法がある。一つ はシリコンラバーなどの印象剤を用いて皮膚表面のレプ リカをとり，それを解析する方法（レプリカ法）と，も う一つはレプリカを介さずに直接, 皮虐表面形状を調べ る方法（in vivo 法）である。さらにレプリカ法は, CCD カメラでレプリカを拡大撮像して画像を解析する方法 (二次元画像解析法 ${ }^{13}$ ) とレーザー光を用いてレプリカ 表面の凹凸を精度よく三次元計測する方法（三次元解析 法 ${ }^{14 ~ 16)}$ ) に分かれる。In vivo 法においても同様で, マイ クロスコープを用いて皮膚表面を撮影し画像解析する方 法 (二次元画像解析法 ${ }^{17}$ ) と格子状のパターンを皮虚に 投影しその画像の歪みから皮虐の三次元情報を得る方法 (三次元解析法 ${ }^{18,19)}$ ) に分かれる。それぞれ操作法, 操作 時間, 測定精度などにおいて特徴があり, 二次元画像解 析法は深さ方向の精度が劣ること, 三次元 in vivo 法は脈 動や体動の影響を受けやすく測定精度が上がらないこと などからレプリカ三次元計測法がよく用いられている。

キメの異方性は加龄変化, あるいはスキンケアによる 肌状態の変化を調べるうえで有効な指標である。若年の 肌ではキメはどの方向にも均一に走向しているが, 加龄 とともに一方向に流れ異方性が強くなる ${ }^{13)}$ 。また，ドラ イスキンの程度が進むほど異方性が目立つようになる。 キメの異方性は二次元画像解析からも測定可能である が, 三次元形状データから FFT（Fast Fourier Transform : 高速フーリエ変換）を行い，キメの方向性を解析するの が一般的である ${ }^{14 \sim 16)}$

\section{5. 皮膚力学測定}

皮䖉力学特性は皮䖉の柔らかさ, 硬さなどの感触やは り・たるみなどを評価するうえで重要で, 皮䖉の応力一 歪特性や音波の伝播速度, 反発力などを利用した様々な
測定原理に基づいた機器が開発されている ${ }^{20)}$ 。In vivoの 測定では角層, 表皮, 真皮に分けてその力学特性を調べ ることは難しいが, 皮䖉に与える変位量を変えることに より, ある程度皮虚樑さ方向における違いを検討するこ とができる。変位を小さくすれば主として皮虞表面（角 層・表皮）の特性が測定でき, 変位が大きい場合には真 皮や皮下組織の影響が強くなる。

数多くある機器の中でもセンサー内部を減圧して隆起 した皮膚の高さから力学特性を調べる cutometer（Courage + Khazaka 社, ドイッ) は一般的に広く用いられて いる ${ }^{21)}$ 。減圧状態（100～500 mb の範囲で可変）を 2 秒 間保ち, その後, 開放したときの時間に対する変位（皮 膚の隆起) 曲線から多くのパラメー夕が測定される。 Uf（減圧 2 秒後の変位量）やUv（遲延的変位量）など は角層水和測定に, Ur/Uf や Ua/Uf などは皮䖉の加齢 変化やはり・たるみの測定に適している。Ur は減圧を 解除したときに瞬間的に戻った変位量を, Ua は 2 秒後 に戻った変位量を示す。プローブの口径や減圧の程度を 変えることにより皮虚に与える変位が変わり, 皮膚墚さ に応じた力学特性が測定できる。

皮虐は皮虐割線(Langer line, ランガー割線) とよばれる 方向に張力が高いため力学的異方性を示す。この方向は 真皮中のコラーゲンやエラスチン線維の配向に基づいて いる。力学的異方性を調べるには音波の伝播速度を利用し た Reviscometer (Courage + Khazaka 社, ドイッ)が用いら れ,ランガー割線に沿った方向では弾性率が高いことや, 加齢にともなって異方性が増すことが報告されている22)。

\section{6. シ ワ 測 定}

シワ測定にはキメ測定と同様，大別するとレプリカを 介してその凹凸を調べる方法とレプリカを取らずに直 接，皮虚を三次元計測する方法（in vivo 法）とがある。 キメと同一の手法を用いるものの, キメ測定では皮溝, 皮丘のパターンの変化が重要であるのに対し, シワ測定 では個々のシワの梁さ, 長さ, 数などが対象となり用い る解析パラメータが異なる。また, シワ改善評価におい ては施術前後における部位の厳密なマッチングが必要で ある。な扔，シワ測定に関しては日本香粧品学会よりガ イドラインが作成されている230

\section{1 斜光照明によるレプリカ二次元画像解析法（斜 光照明法)}

簡便で一般的に用いられる方法である。シワを強調し た画像を作るため, キメ測定とは異なりレプリカに対し 斜め一方向（伏角 20〜30 度）から光を照射し影を作り, 二值化処理して得られた影の部分の高さ, 長さなどから シワの深さ，大きさを算出する。深いシワの陰に隠れた 
小じわの解析ができないこと, シワの深さに関する精度 が低いこと, 二值化の条件によって抽出されるシワが異 なることなど欠点はあるが，照明および撮影装置があれ ばよいので安価で手軽に評価できる。

\section{2 レプリカを用いた三次元解析法}

キメ測定と同様, 共焦点顕微鏡法やレーザー光切断 法, パターン投影法などがある。三次元座標が求まるの で, 斜光照明による画像解析法よりも正確に, またシワ 体積, シワ横断面（深さのプロフィール）など二次元画 像解析では求められない有用なパラメー夕も計算でき る。三次元表示が可能なのでシワ改善の程度を明暸に表 示することができる。

\section{3 In vivo 三次元計測法 ${ }^{18,19)}$}

シワはキメょりも溝が深いので in vivo での三次元計 測が可能である。レプリカ剂の粘稠度によってはシワの 奥まで入らず皮膚表面形状を正しく再現していないケー スが稀にあること，レプリカ刻による閉塞にともなう皮 膚水和によって表面形態が変わる可能性などが考えら れ，レプリカ作成の巧拙によらず非接触で測定できる本 方法は有用である。

\section{7. シ ミ 測 定}

シミはメラニン色素が皮膚に沈着し褐色を呈する斑で 明度や色調が周囲と異なることから，これまで評価には 色彩色差計が広く用いられてきた。専ら L*值から調べ られているが L*值は皮膚の赤みの影響を受けるので微 妙な変化を論じることは難しい。この影響を避けるため 2 波長における皮虐の反射率を利用してメラニン指数を 測定する Mexameter (Courage + Khazaka 社, ドイッ) や Dermaspectrometer (Cortex Technology 社, デンマーク) が開発されているが，まだ若干へモグロビン（赤み）の 影響を受ける。この欠点を改良するため 500〜700 nm の 範囲で皮䖉分光反射率曲線をメラニン, ヘモグロビン（酸 化型および還元型）のスペクトルで重回帰し，それぞれ の量を推定する方法が考案されている ${ }^{24)}$ 。また, デジ夕 ルカメラで撮影した画像の RGB から各画素に扔けるメ ラニン指数や紅斑指数を簡便に算出する方法もある ${ }^{25)}$ 。

\section{8. 皮膚内部を調べる in vivo 生体顕微鏡}

体内の組織を非侵襲的に観察する方法として超音波断 層撮影や MRI, X 線 CT などは医療分野で広く用いられ ているが, 厚さわずか $1 \mathrm{~mm}$ 程度の皮䖉に対しては分解 能が低く, そのままの条件では適用が難しい。近年, 光 バイオプシーとよばれ非侵襲的に皮膚内部の構造や構成 成分を高分解能で調べることのできる技術, in vivo 生体 顕微鏡，が開発されている。非線形光学現象を利用した
多光子顕微鏡や SHG 顕微鏡, CARS 顕微鏡などは皮䖉 内部の観察だけでなく, 経皮吸収測定にも活用され組織 と併せて調べることができる。

\section{1 超音波断層撮影 (ulrasonography)}

皮虐の測定には $20 \mathrm{MHz} \sim 50 \mathrm{MHz}$ の高周波数の機器 が用いられている。空気と角層, 表皮と真皮, 真皮と脂 肪層の界面など密度の異なる二つの層が接する界面では 超音波の反射が強く起こるため, 皮膚表面から入った超 音波の反射強度 (エコー強度) から皮虐深さ方向におけ る断層像を作ることができる。エコー強度の違いから表 皮, 真皮, 皮下脂肪が識別でき, 皮虐厚や脂肪厚の測 定，セルライトや加齢に伴う真皮の状態変化（コラーゲ ンの粗密）の観察などに使われている。

非露光部では加齢とともに表皮厚, 皮虞厚は薄くな る。一方, 露光部に扔いては subepidermal low-echogenic band $(\mathrm{SLEB})^{26)}$ とよばれる真皮上層のエコー強度の弱い 領域が加齢とともに広くなる。これは日光を長い間, 浴び たことによって真皮上層に扔けるコラーゲンが変性・分 解するのでエコーが弱くなるためである。このコラーゲ ンの分布状態に着目してコラーゲンスコアとして簡便に 測定する機器（DermaLab, Cortex Technology）が市販さ れており,サプリメントの効果評価などに使われている27)。

8.2 光コヒーレンス・トモグラフィー (optical coherence tomography : OCT)

OCT は生体に入射された光が組織によって反射され 戻ってくる位置と強度を光の干渉から測定する装置であ る。いってみれば超音波の代わりに光を用いた断層撮影 法であり, 超音波や MRI と比べて分解能は高い。OCT を用いて表皮一真皮界面の形状, 表皮厚などが調べられ ている。また, 手掌のように角層の厚い部位では汗管の 観察や角層厚の測定が可能である。

OCT プローブ光には強度信号だけでなく位相信号も 含まれているので，これを解析することによって皮虐断 層像と同時に種々の情報を得ることができる。ドップラ ーシフトから血流状態を調べる Doppler-OCT ${ }^{28)}$ や偏光を 用いて真皮コラーゲンの状態（光老化 ${ }^{29,30)}$, 熱傷 ${ }^{31,32}$, 基底細胞癌の侵入 ${ }^{33}$ など）を調べる偏光 OCT（Polarization Sensitive-OCT ; PS-OCT) など機能的 OCT とよばれ る方法が開発されている。今やただ単に皮膚の断層像を 撮るだけでなく, 他の情報も含めた解析が行われるよう になっている。

\subsection{In vivo 共焦点レーザー走査型顕微鏡（CLSM）}

皮䖉内に焦点をあててレーザー光を照射し皮䖉の中か ら返ってくる反射光を検出・撮像し, 皮虐水平断面像を 得る。数 $\mu \mathrm{m}$ ごとに焦点位置を変えながら皮䖉表面から 内部に向かって観察すると, 角層, 顆粒層, 有棘層, 基 
底層とその特徵的な細胞が観察される。角層では反射が 強く特徽的な画像は得られないが，角層から顆粒層への 移行は核の有無によって, また基底層においてはキラキ ラ輝くメラニンキャップ (メラニンの集合塊) の輝度の 高い画像が得られることから, その位置がわかる。表皮 一真皮界面では凹凸（表皮突起，真皮乳頭）があるため ところどころ基底層に混じって真皮（ほとんど映像のな い暗い部分）が認められる ${ }^{34)}$ 。真皮では血管や血球の動 き35)，走行したコラーゲンも観察される。

\section{4 多光子顕微鏡 (MPM)}

多光子顕微鏡は近赤外光（波長 700～1100 $\mu \mathrm{m} ）$ を励 起光として皮䖉に照射し, 存在する物質の蛍光特性（蛍 光波長や蛍光寿命）から皮膚組織を観察する。フェムト 秒オーダーの超短パルスレーザーを光源とするため焦点 位置に存在する物質だけが励起される（非線形光学現象 を利用した多光子励起）ので，その蛍光を検出すれば共 焦点装置を使わずに任意の深さの皮虐水平断面像が得ら れる。皮膚にはケラチン, メラニン, $\mathrm{NAD}(\mathrm{P}) \mathrm{H}$, エラ スチン, コラーゲン, リポフスチンなど多くのフルオロ フォア（蛍光を放つ物質）が存在するので, これらを基 に皮虐組織像が得られる。測定深度を変えて, 皮虐各層 における水平断面像を調べると, 角層ではケラチンによ る強い蛍光と六角形を基調とする細胞が観察され, 顆粒 層では細胞質が NAD (P) H とケラチンによる蛍光によっ て明るく,また中央の核は暗く見える。有棘層では核が二 つに分裂している像が時々見られ, 細胞の大きさは顆粒 層から基底層に向かうに従って小さくなる。基底層では メラニンによる強い蛍光が観察される。さらに真皮に扔い ては真皮乳頭でコラーゲンやエラスチンが観察され, 網 状層ではこれらの線維はより鮮明になる ${ }^{36)}$ このように多 光子顕微鏡は生体成分特有の蛍光特性を利用して非侵襲 的に皮膚内部構造を細胞レベルで調べることができる。

皮虐内に存在する物質に対してその蛍光寿命を用いて 画像化する技術, FLIM (fluorescence lifetime imaging microscopy)，はより鮮明な画像を示す。たとえば，ケ ラチノサイト (主に $\mathrm{NAD}(\mathrm{P}) \mathrm{H}$ の蛍光寿命特性を示す) とメラノサイト（主にメラニンの蛍光寿命特性を示す） の蛍光減衰曲線の違いからメラノーマのイメージングが 行われている ${ }^{37)}$ 。また, FLIMを用いてナノ粒子酸化車 鉛（粒径が $200 \mathrm{~nm}$ 以下）の経皮吸収性が調べられてい る。Leite-Silva ら ${ }^{38)}$ は酸化亜鉛を $10 \%$ 濃度で基剤に分散 させ, 前腕屈側に 6 時間塗布（塗布量はSPF 測定と同 程度の $\left.2 \mathrm{mg} / \mathrm{cm}^{2}\right)$ し, NAD $(\mathrm{P}) \mathrm{H}$ の自家蛍光と酸化亜 鉛のフォトルミネッセンスの蛍光寿命から皮膚内におけ る酸化带鉛の分布状態を画像化している。限定的ではあ るが, ナノ粒子酸化亜鉛は顆粒層まで入ること, しか
し, 細胞の酸化還元状態には影響せず必ずしも細胞毒性 を引き起こすわけではないことが報告されている。

\subsection{SHG 顕微鏡}

多光子顕微鏡と同様に,フェムト秒オーダーの超短パ ルスレーザーを皮膚組織に照射するとコラーゲンは入射 光の半分の波長の光 (SHG 光)を発生する。SHG 光も非線 形光学現象で, 焦点の合った位置でしか発生しない。焦点 位置を変えながら SHG 光を検出すれば任意の媣さにお けるコラーゲンの分布状態が水平断面像で観察できる。

この SHG 顕微鏡と多光子顕微鏡とを組合わせること により, in vivo で真皮中のコラーゲンとエラスチンを同 一画像上で示すことができる。通常, 多光子顕微鏡で真 皮を観察すると, コラーゲンとエラスチンの蛍光波長は 近似しており両者を分離して示すことは難しいが，800 $\mathrm{nm}$ 以上の光源を用いて $450 \mathrm{~nm}$ 以上の波長の長い蛍光 をロングパスフィルターで検出すればエラスチンだけが 抽出される。たとえば $850 \mathrm{~nm}$ の光源を用いれば半分の 波長である $425 \mathrm{~nm}$ に SHG 光が（すなわちコラーゲン が）観察され, 多光子顕微鏡で $450 \mathrm{~nm}$ 以上の波長の光 を検出すればエラスチンが観察される ${ }^{39)} 。$

SHG 光はコラーゲンだけでなくナノ粒子からも生じ, これを Hyper-Rayleigh Scattering: HRS, 超レーリー散 乱，とよぶ。そのためこのナノ粒子からの HRS を検出 することにより皮膚中でのナノ粒子の存在を調べること ができる。コラーゲンによる SHG 光は真皮で発生する ので表皮でのナノ粒子からの HRS とは測定深度から区 別され, 多光子顕微鏡で得られた皮虐組織像と対応させ ればナノ粒子の存在位置が確認できる。

Darvin ら ${ }^{40}$ は平均粒径が $30 \mathrm{~nm}$ の酸化亜鉛ナノ粒子の 分散液 $\left(8 \%\right.$ ) を前腕に塗布（塗布量は $2 \mathrm{mg} / \mathrm{cm}^{2}$ ) した 後, MPM/SHG/HRS (DermaInspect ${ }^{\mathrm{TM}}$ ) を用いて粒子の 皮内分布状態を調べている。その結果, ナノ粒子からの HRS 光は角層上層, 皮溝, シワ, 毛穴だけに観察され, 酸化車鉛ナノ粒子は表皮生細胞層には浸透しないと結論 づけている。

\section{6 CARS 顕微鏡}

in vivo 共焦点ラマン顕微鏡 (Confocal Raman Microscope : CRM）は微弱なラマン散乱が共焦点装置のピン ホールで弱められる, あるいは皮虐組織が放つ自家蛍光 によって妨害される場合があるので, 最近ではアンチス トークス散乱光を用いた CARS 顕微鏡が使われている。 CARS は CRM と同様に皮膚の深さ方向に打ける脂質 $\left(\mathrm{CH}_{2}\right)$ や水 $(\mathrm{OH})$ などの情報が得られる。しかし, CRM に比べて強いシグナルが得られること, 非線形光 学現象を利用しているので多光子顕微鏡と同時測定が可 能であることなどメリットは大きい。W/O (water in oil) 
型クリームを皮虞に塗布したときの皮内における油分の 分布状態が MPM/CARS 顕微鏡で調べられている ${ }^{41}$ 。

\section{9. 終わりに}

皮虐計測技術はこの 40 年ほどの間に急速に進歩した。 R. Marks と H. Blank ${ }^{42}$ が, 「modern electronic and other devices have become available for measurements of very small changes in physical or chemical characteristics------, applying these new techniques to the skin-----」と記し, 第 1 回 International Society for Bioengineering and the Skin をマ イアミで開催したのが 1976 年で, 以後, Table 1 に見ら れるように多くの計測技術・機器が開発された。最近の 大きな特徽は, 光の非侵襲性を利用し皮虐を切除せずに 皮膚内部の構造や構成成分を調べることのできる in vivo 生体顕微鏡の開発である。なかでも非線形光学現象を利 用した多光子顕微鏡, SHG 顕微鏡, CARS 顕微鏡など は分解能がきわめて高く細胞レベルで観察できる。今 後, 可視化センサー分子の開発が進み, in vivo で細胞内 での微小な構造や分子の動態を電子顕微鏡に迫る空間分 解能で観察できる日も近いと思われる。

皮虐計測技術の発展とともに「化粧品の効能・効果を 科学的な方法によって評価し (evidence based cosmetics), より機能的で有用な化粧品の開発」が一段と進ん だ。今や皮膚生体工学測定は化粧品研究において必須の 技術となっている。

\section{文献}

1) 江川麻里子, 高橋元次 : “老化防止・美白・保湿化精 品の開発” (シーエムシー出版, 2001) p. 162.

2) I. Horii, Y. Nakayama, M. Obata and H. Tagami : Br. J. Dermatol. 121, 587 (1989).

3) R.O. Potts, D.B. Guzek, R.R. Harris and J.E. Mckie : Arch. Dermatol. Res. 277, 489 (1985).

4) F. Damien and M. Boncheva : J. Invest. Dernatol. 130, 611 (2010).

5) J. de Rigal, M.J. Losch, R. Bazin et al. : J. Soc. Cosmet. Chem. 44, 197 (1993).

6) M. Egawa, M. Yanai, K. Kikuchi and Y. Masuda : Appl. Spectrosc. 65, 924 (2011).

7) F. Mirraashed and J.C. Sharp : Skin. Res. Technol. 10, 14 (2004).

8) E. Ciampi, M. van Ginkel, P.J. Mcdonald et al : NMR Biomed. 24, 135 (2011).

9) P.J. Caspers, G.W. Lucassen, E.A. Carter, H.A. Bruining and G.J. Puppels : J. Invest. Dermatol. 116, 434 (2001).

10) P.M. Elias : J. Invest. Dermatol. 125, 183 (2005).

11) 高橋元次 : COSME TECH JAPAN, 2, No. 9 (9 月号), 5 (2012).

12) H. Mochizuki, H. Tadaki, S. Takami et al. : Br. J. Dermatol. 160, 972 (2009).
13) 高橋元次 : “現代皮膚科学大系, 年刊版 ’90-B” (中山書 店, 1990) p. 13

14) H. Zahouani, R. Vargiolu and P. Humbert : $20^{\text {th }}$ IFSCC Congress, Cannes (1998).

15) M. Setaro : Skin Res. Technol. 7, 159 (2001).

16) J.M. Lagarde, C. Rouvrais and D. Black: Skin Res. Technol. 11, 110 (2005).

17) 荒川尚美, 大西浩之, 外田勇二: 粧技誌 41, 173 (2007).

18) S. Jaspers, H. Hopermann, G. Sauermann, U. Hoppe, R. Lunderstadt and J. Ennen: Skin Res. Technol. 5, 195 (1999).

19) M. Rohr and K. Schrader: SOFW 124, 52 (1998).

20) 高橋元次 : COSME TECH JAPAN, 2, No. 12 (12 月号), 19 (2012).

21) A.B. Cua, K.P. Wilhelm and H.I. Maibach : Arch. Dermatol. Res. 282, 283 (1990).

22) E.C. Ruvolo, G.N. Stmatas and N. Kollias: Skin Pharmacol. Physiol. 20, 313 (2007).

23) 日本香粧品学会 抗老化機能評価専門委員会: 日本 香粧品学会誌 30, 316 (2006).

24) 外田勇二, 高橋元次, 坂本哲夫, 島田美帆, 伊藤雅英, 谷田貝豊彦: 粧技誌 35, 325 (2001).

25) T. Yamamoto, H. Takaiwaki, S. Arase et al. : Skin Res. Technol. 14, 26 (2008).

26) M. Gniadecka et al. : J. Invest. Dermatol. 102, 362 (1994).

27) S. De Spirt et al. : Skin Pharmacol. Physiol. 25, 2 (2012).

28) L.L. Otis, D. Piao, C.W. Gibson and Q. Zhu : Oral Surg., Oral Med., Oral Pathol., Oral Radiol., Endod. 98, 189 (2004).

29) M.C. Pierce, J. Strasswimmer, B.H. Park and J.F. de Boer : J. Biomed. Opt. 9, 287 (2004).

30) S. Sakai et al. : J. Invest. Dermatol. 128, 1641 (2008).

31) S.M. Srinivas, J.F. de Boer, H. Park and K. Keikhanzadeh : J. Biomed. Opt. 9, 207 (2004).

32) M.C. Pierce, R.L. Sheridan, B.H. Park, B. Cense and J.F. de Boer: Burns 30, 511 (2004).

33) J. Strasswimmer, M.C. Pierce, V. Neel and J.F. de Boer : J. Biomed. Opt. 9, 292 (2004).

34) 高橋元次: “美容皮膚科学” (南山堂, 2009) p. 160.

35) J. Hegyi, V. Hegyi, G. Messer et al. : Skin Res Technol. 15, 476 (2009).

36) K. Schenke-Layland et al. : Advanced Drug Delivery Reviews 58, 878 (2006).

37) E. Dimitrow et al. : Exp Dermatol. 18, 509 (2009).

38) V.R. Leite-Silva et al. : Eur. J. Pharm. Biopharm, 84, 297 (2013).

39) G. Chen et al. : Br. J. Dermatol. 161, 48 (2009).

40) M.E. Darvin et al. : Skin Pharmacol. Physiol. 25, 219 (2012).

41) H.G. Breunig, R. Buckle, M. Keliner-Hofer et al. : Micros. Res. Tech. 75, 492 (2012).

42) R. Marks and H. Blank : J. Invest. Dermatol. 69, 275 (1977). 